American Journal of Applied Sciences 7 (4): 466-472, 2010

ISSN 1546-9239

(c) 2010Science Publications

\title{
Dairy Heifer Rearing in Hot Arid Zone: An Economic Assessment
}

\author{
M.A. Razzaque, S.A. Mohammed and T. Al-Mutawa \\ Department of Aridland Agriculture and Greenery, \\ Kuwait Institute for Scientific Research, P.O. Box 24885, Safat 13109, Kuwait
}

\begin{abstract}
Problem statement: Economic losses due to high mortality in young calves born in hot arid zone including Kuwait and a high cost of rearing are the main constraints to this region. Therefore, dairy producers have to depend on importation of pregnant heifers for herd replacement. Research data on cost of heifer rearing from their weaning to first lactation were lacking. The objectives of the present investigation were to compare the costs/benefits of raising heifers born in Kuwait without and with intervention measures and project the future financial benefits. Approach: Present study methods involved using cost-benefit model where without and with intervention scenarios were compared using a total of 58 herd parameters. These variables included in the spreadsheets in the model could be varied during each year of projection period. Production turnoff of 3 herds each of 245 cows in three scenarios namely baseline, improved and future were evaluated. Input costs of imported heifers (baseline), locally raised heifers with interventions (improved) and projected 10 year (future) and the income generated from these scenarios were analyzed. Results: Total income generated from baseline, improved and the future projection were KD 268,715/-, 281,246/-and 342,251/respectively $(1 \mathrm{KD}$ Kuwaiti Dinar = US \$3.45); total operating costs of these scenarios were KD 249,372/-, 242,276/-and 205,929/-respectively. Financial analyses showed that benefits were double when interventions were applied KD 19,343/-Vs KD 38,970/-in baseline and improved operation respectively. Conclusion: Fifty percent of the total heifers needed for herd replacement could be sourced locally showing an increased net income as an outcome of intervention measures. Locally born adapted heifers could be used for dairying in this hot arid zone with a phase-wise increase in their herd size reducing dependence on imported dairy cattle.
\end{abstract}

Key words: Dairy heifers, economic assessment, interventions, financial analysis

\section{INTRODUCTION}

Many countries of hot arid zone including Kuwait do not possess a dairy cattle breed of their own, therefore, depend on imported Holstein Friesian cattle. Imported pregnant heifers are exposed to an extreme hot arid feedlot environment. After their calving and subsequent breeding, they can last for 2-3 lactations. In Kuwait, the calves born from unadapted imported dams suffer from a very high mortality rate. Mean crude mortality rate was 43.6\% in 1997 (Razzaque et al., 2009a). Observing the high young calf losses in Kuwait, studies were initiated in 1998 to investigate the causes of calf mortality. The management constraints and the pathogens causing the high death rates were identified. Intervention measures were undertaken in the commercial dairy farms from year 1999 through 2006 resulting in a phase-wise reduction of crude mortality rate of pre-weaned calves from mean high of $43.6 \%$ to a low of $4 \%$ (Razzaque et al., 2009b). Subsequent work in Kuwait involved raising of heifers from their 91d age through their breeding and lactation stages.

Published information on cost/benefit analysis of replacement heifer rearing in Kuwait and under similar hot arid zones is scanty. In addition, dairy producers in this region are hesitant to undertake the venture of heifer raising as the economic data and the cost/benefit analyses are limited. Studies conducted in Kuwait (Razzaque et al., 2009c) showed encouraging results with a significant reduction of calf losses and improvement in growth rate of pre-weaned HolsteinFriesian calves born from imported cows when they were housed in hutches. Improved management practices and heat detection of heifers at their first mating were found to have reduced heifer rearing cost by $40 \%$ (Heersche et al., 1994; Tenhagen et al., 2004).

Corresponding Author: M.A. Razzaque, Department of Aridland Agriculture and Greenery,

Kuwait Institute for Scientific Research, P.O. Box 24885, Safat 13109, Kuwait

Tel: +965 24989828 Fax: (965) 2498-9809 
Am. J. Applied Sci., 7 (4): 466-472, 2010

Economic analysis of heifer rearing was carried out in the Virginia Tech. Cooperative by Bailey (1999) and Ohio State University. Bailey and Currin (1999) reported economic feasibility of heifer rearing from the ages of 3-23 months. Total costs of raising heifers were on feeds, laborers and utility ranged from US $\$ 1000$ /-to $\$ 2000 /$-per heifer, representing $\$ 1.50$ $3.00 \mathrm{~h}^{-1}$ day $^{-1}$ and a gross costs ranged from $\$ 50$ $60 / \mathrm{month} /$ head. In the USA, assessments of heifer rearing expenses were estimated by many investigators earlier (Head, 1992; Baily, 1992; Mourtis et al., 1997; Harash et al., 1998). Most of the previous analyses of the heifer growth issues had used average or estimated marginal costs to assess savings. While the costs to raise a heifer vary widely across the farms and management schemes. These costs could be partitioned into those costs that were likely to vary with faster growth rates (e.g., breeding and vaccines), costs that will change a function of growth rate (feed) and the duration of the heifer growing period (Harash et al., 1998). They found that feed was the most important cost factor which changed with the growth rate of heifers. As the heifers grew faster, the relative percent of feed consumption used for maintenance declined, which indicated that an accelerated growth was effective in feed cost savings.

In Kuwait, studies on feasibility of heifer rearing from weaning to breeding and calving ages are not available. Our recent economic assessment data on calf rearing from birth to the weaning at 90 days in Kuwait (Razzaque et al., 2009c) on biological performance of locally born heifers (Razzaque et al., 2009d) formed a strong basis for undertaking the present study. The objectives of this investigation were to compare the costs/benefits of replacement heifer raising in Kuwait without and with intervention measures and make projections on future financial benefits of the enterprises.

\section{MATERIALS AND METHODS}

The approach of the study involved the use of benefit-cost framework where the 'with' and 'without' interventions and projected future scenario in the whole dairy farm were compared.

Scenarios for the financial analysis: Using three herds each of 245 dairy cows, the model was used to compare three scenarios. The variables of herd performance in baseline, improved and projected future scenarios (10 year) are given in Table 1.
Table 1: Herd performance parameters

\begin{tabular}{|c|c|c|c|}
\hline & Baseline & Improved & Future \\
\hline \multicolumn{4}{|l|}{ Calving (\%) } \\
\hline Imported cows & 95 & 95 & 95 \\
\hline \multicolumn{4}{|l|}{ Imported cows (years) } \\
\hline 3 & 50 & 50 & 85 \\
\hline $4+$ & 50 & 50 & 85 \\
\hline Local heifers & 95 & 95 & 95 \\
\hline \multicolumn{4}{|l|}{ Local cows (years) } \\
\hline 3 & 50 & 50 & 85 \\
\hline $4+$ & 50 & 50 & 85 \\
\hline \multicolumn{4}{|l|}{ Mortalities (\%) } \\
\hline \multicolumn{4}{|l|}{ Female calves } \\
\hline 1 week & 24 & 3 & 3 \\
\hline 1 week to 3 months & 15 & 1 & 1 \\
\hline 3-6 months & 7 & 2 & 2 \\
\hline Females 7-18 months & 2 & 2 & 2 \\
\hline Local heifers $19-30$ months & 2 & 2 & 2 \\
\hline Local cows 3-4 years & 3 & 3 & 3 \\
\hline Local cows $4-10$ years & 3 & 3 & 3 \\
\hline Imported Heifers & 2 & 2 & 2 \\
\hline \multicolumn{4}{|l|}{ Imported cows (year) } \\
\hline 3 & 3 & 3 & 3 \\
\hline 3-10 & 3 & 3 & 3 \\
\hline \multicolumn{4}{|l|}{ Male calves } \\
\hline 1 week & 24 & 3 & 3 \\
\hline 1 week to 3 months & 15 & 1 & 1 \\
\hline 3 months to 6 months & 4 & 2 & 2 \\
\hline Males 7-18 months & 1 & 2 & 2 \\
\hline Herd bulls & 4 & 3 & 3 \\
\hline \multicolumn{4}{|l|}{ Culling rates (\%) } \\
\hline \multicolumn{4}{|l|}{ Breeders imported (year) } \\
\hline $3-4$ & 50 & 50 & 25 \\
\hline $4-5$ & 50 & 50 & 25 \\
\hline $5-6$ & 100 & 100 & 25 \\
\hline $6-7$ & 100 & 100 & 100 \\
\hline $7-8$ & 100 & 100 & 100 \\
\hline $8-9$ & 100 & 100 & 100 \\
\hline $9-10$ & 100 & 100 & 100 \\
\hline $10-11$ & 100 & 100 & 100 \\
\hline \multicolumn{4}{|l|}{ Breeders local (year) } \\
\hline 3-4 & 50 & 50 & 25 \\
\hline $4-5$ & 50 & 50 & 25 \\
\hline $5-6$ & 100 & 100 & 20 \\
\hline $6-7$ & 100 & 100 & 50 \\
\hline $7-8$ & 100 & 100 & 100 \\
\hline $8-9$ & 100 & 100 & 100 \\
\hline $9-10$ & 100 & 100 & 100 \\
\hline 10-11 & 100 & 100 & 100 \\
\hline Herd bulls & 25 & 25 & 25 \\
\hline Replacement cows-imported (\%) & 100 & 0 & 0 \\
\hline Percentage if sales (of balance re & emaining) & & \\
\hline Female calves & & & \\
\hline 1 week & 100 & 0 & 0 \\
\hline 3 months & 0 & 0 & 0 \\
\hline 6 months & 0 & 5 & 10 \\
\hline 12 months & 0 & 10 & 5 \\
\hline Male calves & & & \\
\hline 1 week & 0 & 0 & 0 \\
\hline 3 months & 20 & 0 & 0 \\
\hline 6 months & 50 & 0 & 0 \\
\hline Mating & & & \\
\hline $\begin{array}{l}\text { Artificial imnsemination } \\
\text { (local heifers only) }\end{array}$ & 0 & 0 & 0 \\
\hline Bull joining rate (\%) & 5 & 5 & 5 \\
\hline Milk production-liters/lactation & & & \\
\hline Imported cows (lactation) & & & \\
\hline $1 \mathrm{st}$ & 5083 & 5083 & 6800 \\
\hline 2nd & 5383 & 5383 & 7000 \\
\hline 3rd & 5217 & 5217 & 7000 \\
\hline 4th & 5167 & 5167 & 7000 \\
\hline Local cows (lactation) & & & \\
\hline $1 \mathrm{st}$ & 4083 & 4083 & 6800 \\
\hline 2nd & 4167 & 5383 & 7000 \\
\hline 3rd & 4167 & 5217 & 7000 \\
\hline 4th & 4167 & 5167 & 7000 \\
\hline
\end{tabular}


Baseline: This was the traditional dairy cattle operation in the absence of any of the intervention measures for improvement was largely based on baseline data (Razzaque et al., 2009a; 2009b) and the experience with the industry-base survey. Only a small proportion of replacement animals were locally bred and for simplicity, it was assumed that all replacement dairy herds were imported in the baseline scenario.

Improved: This was an improved farm enterprise where the results and recommendations of the experimental work done in Kuwait farms and intervention measures were applied to the commercial dairy farms (Razzaque et al., 2009c). Because the practice of culling imported cows after an average of 2.3 lactations in Kuwait, the number of heifers that could be raised was insufficient to replace all of the imported cows because of a quick turnover of the cows by culling, but a significant inroads could be made. There was some capital expenditure involved with calf raising hutches (Razzaque et al., 2009d), additional accommodation for the increase in animal numbers and some equipment necessary to implement the recommended intervention measures were used based on the findings of the applied research in the dairy farms.

Future projections (10 year): A hypothetical model was used based on experience with improved dairy enterprises elsewhere in the region, which could take the industry further along the improved efficiency path in order to take full advantage of the improvements which were demonstrated in Kuwait through the applied studies (Razzaque et al., 2009a; 2009b; 2009c). Locally bred animals were carried through a number of lactations in the milking herd and their productivity was to be significantly improved through better breeding practices by Artificial Insemination (AI) using imported USA origin frozen semen of Holstein Friesian breed, improved nutrition, feeding and overall management of the enterprise (Razzaque et al., 2009b). It included some cooling of the animal shed environment during the summer season to assist in feed intake, reproduction and modest rises in milk production were also built in the model and spreadsheets.

Additional capital expenditure would be required as a result, including some evaporative coolers and feed mixing equipment.

Whole farm financial analysis: The whole farm financial results presented in this study were partial budgets containing the most important of the operating expenses, but did not include fixed costs. Such information was not fully available at that time, but this was not important when comparing three scenarios of interest only. In this situation, the fixed and other costs were common to all situations and did not change from one model/scenario to the next.

Economic model and variables of assessment: The model was developed in 1998 using spread sheets and reported earlier (Razzaque et al., 2009a; 2009c). The model involved a dairy herd structure analysis which took the herd numbers, production and fertility variables and projecting the possible changes in herd structure over a ten year period. A total of 58 herd performance variables were included in the spreadsheets and model, all of which could be varied for each year of the projection period (Table 2). The parameters included mortalities, calving and culling rates for a range of animal classes and ages; the age of selling for locally born progeny; provision for an increasing incidence of AI; and milk yields differentiated by age and whether the cow was imported or locally bred.

The model automatically produced a herd size with a specified number of milking cows each year, as it was important to compare farms of the same size or milk output. This aspect was important as some farms had a restriction in the farm space available for raising the progeny and could not do so without a reduction in the number of milking cows. Other farmers might decide that they did not want to increase their production of over-quota milk and may reduce cow numbers as production per cow increases, which would enable some of the progeny to be raised in a limited space situation. The model was capable of incorporating such management strategies.

Herd numbers and structures: Baseline dairy herd size in Kuwait varied considerably. However, average herd size of 245 milkers (Table 2) was common, therefore, an operation of 245 herd size was used for the financial analysis. The locally born heifers were to be introduced showing the herd management input and output of animals. An average total herd sizes were thus in the baseline, improved and projected future scenarios were 265, 464 and 460 dairy cattle (milkers and other herds), respectively (Table 2). In those cases, the locally born heifers are to be retained as replacement herd for breeding.

Costs and financial data: From the dairy herd data, it is a simple task to generate much of the required financial data over a ten year period, using unit costs per animal for feeds and veterinary medicines, as well 
as income using milk production, turnoff data and unit sale prices. Other costs data such as labor, water, power, repairs and maintenance and administration costs were included.

Table 2: Dairy herd numbers and structures

\begin{tabular}{|c|c|c|c|}
\hline & Baseline & Improved & Future \\
\hline Farm size-number of milkers & 245 & 245 & 245 \\
\hline \multicolumn{4}{|l|}{ Breeders B/f (imported) (year) } \\
\hline $3-4$ & 91 & 44 & 0 \\
\hline $4-5$ & 44 & 21 & 0 \\
\hline $5-6$ & 0 & 0 & 0 \\
\hline $6-7$ & 0 & 0 & 0 \\
\hline $7-8$ & 0 & 0 & 0 \\
\hline $8-9$ & 0 & 0 & 0 \\
\hline $9-10$ & 0 & 0 & 0 \\
\hline \multicolumn{4}{|l|}{ Breeders B/f (locally bred) (year) } \\
\hline $3-4$ & 0 & 47 & 71 \\
\hline $4-5$ & 0 & 23 & 51 \\
\hline $5-6$ & 0 & 0 & 40 \\
\hline $6-7$ & 0 & 0 & 19 \\
\hline $7-8$ & 0 & 0 & 0 \\
\hline $8-9$ & 0 & 0 & 0 \\
\hline $9-10$ & 0 & 0 & 0 \\
\hline Replacement heifers (local) & 0 & 97 & 96 \\
\hline Breeders mated & 136 & 232 & 277 \\
\hline Replacement cows (imported) & 186 & 90 & 0 \\
\hline Less culls & 179 & 179 & 89 \\
\hline Less deaths & 8 & 8 & 7 \\
\hline Breeders C/f & 136 & 136 & 181 \\
\hline Female calves & 123 & 123 & 123 \\
\hline Less deaths & 29 & 7 & 7 \\
\hline Less sales at 1 week & 93 & 0 & 0 \\
\hline Less sales at 3 months & 0 & 0 & 0 \\
\hline Less sales at 6 months & 0 & 6 & 12 \\
\hline Females 6 months C/f & 0 & 110 & 104 \\
\hline Females 6 months B/f & 0 & 110 & 104 \\
\hline Less deaths & 0 & 2 & 2 \\
\hline Less sales at 12 months & 0 & 11 & 5 \\
\hline Available for breeding & 0 & 97 & 97 \\
\hline Replacements & 0 & 97 & 96 \\
\hline Non-Replacements Sold & 0 & 0 & 1 \\
\hline Balance C/f 18 months & 0 & 0 & 0 \\
\hline Heifers 18 months B/f & 0 & 0 & 0 \\
\hline Less deaths & 0 & 0 & 0 \\
\hline Available for breeding & 0 & 0 & 0 \\
\hline Less replacements at 24 months & 0 & 0 & 0 \\
\hline Balance sold & 0 & 0 & 0 \\
\hline Male calves & 123 & 123 & 123 \\
\hline Less deaths & 46 & 7 & 7 \\
\hline Less sales at 1 week & 0 & 0 & 0 \\
\hline Less sales at 3 months & 16 & 0 & 0 \\
\hline Less sales at 6 months & 30 & 0 & 0 \\
\hline Balance 6 months C/f & 30 & 115 & 115 \\
\hline Males B/f 6 months & 30 & 115 & 115 \\
\hline Less deaths & 0 & 1 & 1 \\
\hline Balance sold at 12 months & 30 & 114 & 114 \\
\hline Bulls B/f & 5 & 8 & 10 \\
\hline Plus replacements & 2 & 4 & 4 \\
\hline Bulls required & 7 & 12 & 14 \\
\hline Less deaths & 0 & 0 & 0 \\
\hline Less culls & 2 & 3 & 3 \\
\hline Bulls C/f & 5 & 8 & 10 \\
\hline Average number of animals & 265 & 464 & 460 \\
\hline
\end{tabular}

\section{RESULTS}

Financial and economic analyses: The main emphasis of the present study was financial analysis related to private commercial dairy producers, their costs and benefits in rearing replacement heifers in Kuwait. However, involvement of public resource input on dairy cattle production such as infrastructures (roads, water, electricity and marketing) extension services and subsidies needed to be considered. Therefore, the dairy subsector as a whole needed to be economically as well as financially viable. The results of this presented analyses of three scenarios included were herd structures, production level, commodity prices, input costs and projections of cost/benefit in an extended 10 year period. The dairy herds of all classes starting from weaned calves to milking cows of both imported and locally obtained herds are shown for three scenarios in Table 2. Number of animals differed with differences in scenarios.

Herd production and input costs: The production turn off of the dairy herd I, three scenarios are shown in Table 3 and the commodity prices i.e., milk and turnoff the herds are given in the Table 4 . The data of Table 2 and 3 formed the basis for financial analysis. The prices input of the enterprise comprising of imported pregnant dairy heifers, feed cost, veterinary and labor expenses are given in Table 5 . The input cost of pregnant heifers was very high (KD 620/heifer, KD 1 = US\$3.45) followed by feed cost for all classes of dairy herds. The labor cost of the total herd also formed a substantial amount.

Table 3: Herd production

\begin{tabular}{lrrr}
\hline & Baseline & Improved & Future \\
\hline Turnoff: Numbers & & & \\
Breeder culls (imported) & 179 & 86 & 0 \\
Breeder culls (local) & 0 & 93 & 89 \\
Female calves (1 week) & 93 & 0 & 0 \\
Females (months) & & & \\
$\quad 3$ & 0 & 0 & 0 \\
6 & 0 & 6 & 12 \\
$\quad 12$ & 0 & 11 & 5 \\
Local heifers (24 months) & 0 & 0 & 0 \\
Male calves (1 week) & 0 & 0 & 0 \\
Males (month) & & & \\
$\quad 3$ & 30 & 0 & 0 \\
$\quad 6$ & 30 & 114 & 0 \\
$\quad 12$ & 2 & 3 & 314 \\
Culled herd bulls & 350 & 312 & 222 \\
Total turnoff & 795 & 139 & 1380 \\
Manure @ 3 m ${ }^{3}$ head $^{-1}$ year $^{-1}$ & 1247561 & 1156787 & 1674386 \\
Total milk production (L) & 873292 & 809751 & 1172071 \\
Quota @ 70\% (L) & 249512 & 231357 & 334877 \\
Non-quota @ 20\% (L) & 124756 & 115679 & 167439 \\
Direct sales @ 10\% (L) & & & \\
\hline
\end{tabular}


Am. J. Applied Sci., 7 (4): 466-472, 2010

Table 4: Prices of different commodities

\begin{tabular}{|c|c|c|}
\hline Commodity prices & Baseline & Improved \\
\hline \multicolumn{3}{|l|}{ Fresh milk } \\
\hline Quota KD L ${ }^{-1}$ & 0.170 & 0.170 \\
\hline Non Quota KD L ${ }^{-1}$ & 0.140 & 0.140 \\
\hline Direct Sales KD L ${ }^{-1}$ & 0.150 & 0.150 \\
\hline \multicolumn{3}{|l|}{ Turnoff livestock } \\
\hline Breeder culls (imported) & 250.000 & 250.000 \\
\hline Breeder culls (local) & 250.000 & 250.000 \\
\hline Female calves ( 1 week) & 50.000 & 50.000 \\
\hline Females (3 months) & 100.000 & 100.000 \\
\hline Females (6 months) & 200.000 & 200.000 \\
\hline Females (12 months) & 300.000 & 300.000 \\
\hline Local heifers 24 months & 350.000 & 350.000 \\
\hline Male calves 1 week & 50.000 & 50.000 \\
\hline Males 3 months & 100.000 & 100.000 \\
\hline Males 6 months & 200.000 & 200.000 \\
\hline Males 12 months & 300.000 & 300.000 \\
\hline Culled herd bulls & 350.000 & 350.000 \\
\hline Manure $\mathrm{KD} \mathrm{m}^{-3}$ & 3.000 & 3.000 \\
\hline \multicolumn{3}{|c|}{ KD: Kuwaiti Dinar 1 KD = US \$3.45 (exchange rate changeable) } \\
\hline \multicolumn{3}{|l|}{ Table 5: Prices of Input in Two-Scenarios } \\
\hline Input prices & Baseline & Improved \\
\hline Imported pregnant cows KD/head & 620.00 & 620.00 \\
\hline Herd bulls KD/head & 470.00 & 470.00 \\
\hline Feed costs-milking cows KD/lactation & 372.00 & 372.00 \\
\hline Dry cows KD/month & 26.00 & 26.00 \\
\hline Female calves to 1 week & 1.05 & 1.12 \\
\hline Female calves 1 week to 3 months & 15.00 & 16.00 \\
\hline Females 3-6 months & 35.00 & 39.00 \\
\hline Females 6-12 months & 114.00 & 138.00 \\
\hline Heifers $12-15$ months & 76.50 & 94.50 \\
\hline Heifers $15-24$ months & 280.00 & 343.00 \\
\hline Male calves to 1 week & 1.05 & 1.12 \\
\hline Male calves 1 week- 3 months & 15.00 & 16.00 \\
\hline Males 3-6 months & 35.00 & 39.00 \\
\hline Males 6-12 months & 114.00 & 138.00 \\
\hline Herd bulls KD year ${ }^{-1}$ & 350.00 & 350.00 \\
\hline Additional veterinary expenses & 0.00 & 0.00 \\
\hline Birth to weaning & 0.00 & 19.00 \\
\hline Weaning to breeding & 0.00 & 15.50 \\
\hline Breeding/pregnancy & 0.00 & 10.50 \\
\hline Dairy and milking & 0.00 & 6.50 \\
\hline Labor & 14973.00 & 16863.00 \\
\hline
\end{tabular}

Financial analysis: Table 6 presents the capital and operating expenses and income generation from the enterprise in three scenarios. The capital cost was not included in the baseline scenario, whereas, in both improved and future scenarios additional equipment and facilities were included incurring $\mathrm{KD} 12,778$ in both. However, a substantial improvement was planned in providing cooling in the future scenario with a cost of KD 30,309/-, thus total capital cost including above equipment and facilities increased to KD 53,087/-for the future projected scenario (Table 6). The total income in three operations baseline, improved operation and future (10 years) were KD 268,715/-, 281,246 and 342,251, respectively. The total partial operating costs for these farms were KD 249,372/-, 242,276/-and 205,929/-, respectively.
Table 6: Financial analysis (amount in KD)

\begin{tabular}{|c|c|c|c|}
\hline & Baseline & Improved & Future \\
\hline \multicolumn{4}{|l|}{ Additional capital expenditure } \\
\hline Koral koolers & 0 & 0 & 30309.03 \\
\hline Feed mixer & 0 & 0 & 10000.00 \\
\hline $\begin{array}{l}\text { Animal accommodation } \\
\text { (yards and sheds) }\end{array}$ & 0 & 3600 & 3600.00 \\
\hline Calf Hutches and cooling & 0 & 6713 & 6713.00 \\
\hline Milk mixer & 0 & 180 & 180.00 \\
\hline Scales & 0 & 1800 & 1800.00 \\
\hline Refrigeration & 0 & 485 & 485.00 \\
\hline Total capital expenditure & 0 & 12778 & 53087.00 \\
\hline Income & & & 0.00 \\
\hline \multicolumn{4}{|l|}{ Milk sales } \\
\hline Quota & 148460 & 137658 & 199252.00 \\
\hline Direct sales & 34932 & 32390 & 46883.00 \\
\hline Non quota & 18713 & 17352 & 25116.00 \\
\hline Heifer subsidy @100 KD & 0 & 9660 & 9682.00 \\
\hline \multicolumn{4}{|l|}{ Turnoff sales } \\
\hline Breeder culls (imported) & 44669 & 21534 & 0.00 \\
\hline Breeder culls (local) & 0 & 23140 & 22153.00 \\
\hline Female calves 1 week & 4655 & 0 & 0.00 \\
\hline Females 3 months & 0 & 0 & 0.00 \\
\hline Females 6 months & 0 & 1153 & 2306.00 \\
\hline Females 12 months & 0 & 3220 & 1529.00 \\
\hline Local heifers 24 months & 0 & 0 & 0.00 \\
\hline Male calves 1 week & 0 & 0 & 0.00 \\
\hline Males 3 months & 1583 & 0 & 0.00 \\
\hline Males 6 months & 6078 & 0 & 0.00 \\
\hline Males 12 months & 9058 & 34155 & 34155.00 \\
\hline Culled herd bulls & 569 & 986 & 1175.00 \\
\hline Manure sales & 2386 & 4173 & 4139.00 \\
\hline Total income & 268715 & 281246 & 342251.00 \\
\hline \multicolumn{4}{|l|}{ Partial operating costs } \\
\hline Purchase imported cows & 115618 & 55726 & 0.00 \\
\hline Purchase herd bulls & 900 & 11 & 15.00 \\
\hline Labor & 14973 & 16863 & 18549.00 \\
\hline \multicolumn{4}{|l|}{ Feed costs } \\
\hline Milking cows & 89689 & 89693 & 89773.00 \\
\hline Dry cows & 12334 & 6167 & 6179.00 \\
\hline Female calves to 1 week & 98 & 133 & 133.00 \\
\hline Female calves 1 week- 3 months & 0 & 1892 & 1892.00 \\
\hline Females 3-6 months & 0 & 4430 & 4317.00 \\
\hline Females 6-12 months & 0 & 14963 & 14208.00 \\
\hline Heifers $12-15$ months & 0 & 9128 & 9150.00 \\
\hline $15-24$ months & 0 & 0 & 0.00 \\
\hline Male calves to 1 week & 98 & 133 & 133.00 \\
\hline Male calves 1 week- 3 months & 1173 & 1892 & 1892.00 \\
\hline Males 3-6 months & 2127 & 4496 & 4496.00 \\
\hline Males 6-12 months & 3453 & 15791 & 15791.00 \\
\hline Herd bulls & 2374 & 4065 & 4846.00 \\
\hline \multicolumn{4}{|l|}{ Additional feed-future model only } \\
\hline Repairs and maintenance & 2087 & 2087 & 2087.00 \\
\hline Veterinary supplies & 1217 & 1217 & 1217.00 \\
\hline $\begin{array}{l}\text { Additional veterinary expenses } \\
\text { (improved) }\end{array}$ & 0 & 7802 & 7808.00 \\
\hline Water & 1361 & 1361 & 1361.00 \\
\hline Power & 583 & 583 & 583.00 \\
\hline Bedding sand/straw & 687 & 687 & 687.00 \\
\hline Administration costs & 600 & 600 & 600.00 \\
\hline Total partial operating costs & 249372 & 242276 & 205929.00 \\
\hline Partial operating surplus & 19343 & 38970 & 136322.00 \\
\hline
\end{tabular}

The operating surpluses were KD 19,343/-, 38,970/-and $136,322 /-$, respectively. The results of analyses clearly indicated financial benefits were double when interventions were applied i.e., KD 19,343 Vs KD 38,970 in baseline and improved operation. 


\section{DISCUSSION}

Government supports: It was expected that the Government of Kuwait would provide continued good extension services and other direct support on input to the commercial dairy producers. However, it was revealed that the Government support to the subsector was not continuous but interrupted on input such as subsidies on feeds and health services. Therefore, the farmers were providing additional capacity in their water supplies, equipment and buildings from their own resources and/or with loan funds. Under these circumstances, a financial analysis was found to be more appropriate in this study.

Raising of heifers for replacement purposes (the "improved" model) without any changes in the milking herd structure would not result in sufficient numbers to completely replace imports. The "future" model indicates that with additional changes in the herd structure and improving performance of the milking herd, including retaining the cows in the herd for longer periods, total replacement from locally bred heifers would be possible. In that future scenarios (10 years) the operating surplus of KD 136,322 was projected (Table 6).

Calf survival: The improvement in calf survival resulted in a large increase in the number of males and females raised and sold for meat at 6-12 months (Table 6). The impact of this was shown in the previous biological and economic impact studies (Razzaque et al., 2009a; 2009d). Achieving a high calf survival rate was the main emphasis of Norwegian dairy producers for reducing economic losses. The Norwegian dairy achieved mean calf mortality rate of $4.6 \%$ (Gulliksen et al., 2009). These results were consistent with a mean pre-weaned calf mortality rate of $4.2 \%$ in Kuwait's farm where the intervention measures were implemented (Razzaque et al., 2009b; 2009d).

When increased calf survival was coupled with the raising of replacement heifers, the impact was demonstrated by a comparison with the baseline and improved scenarios (Table 6). Even if all the heifers were raised, the number would be insufficient to completely replace imported cows; only around 50\% replacement would be possible. This was because of the traditional practice of only milking cows for an average of 2.3 lactations, selling them into the meat trade, thus resulting in a faster turnover of the milking herds than usual dairy farming operations. That seemed a wasteful practice, but prices for meat in Kuwait are such that it was profitable.

Improvement potential: There was an increase in the net income (Table 5) in the cooperating farms resulting from adoption of applied research intervention measures (Razzaque et al., 2009d). However, the full potential benefits of such innovation can not be realized unless similar improvements in productivity are also promoted in the rest of the herds of the entire dairy industry in Kuwait and similar climatic zone. This could be achieved through the extension work and demonstration of the improved dairy herd management technology.

Cost rearing replacement heifers: Our present studies showed that the input cost of rearing heifers born and adapted in the Kuwait was quite high. Recent studies showed locally reared and bred cows could thrive well for over 4 lactations with their 2 times more milk yield compared to imported cows (Razzaque et al., 2009e). Total input cost of rearing heifers from their 3-24 months age till first lactation was KD 514/heifer (US\$1,749 in 2005) and the feed cost represented $84.6 \%$ of the total input cost. Moore et al. (2009) found that $63 \%$ of the input cost was represented by feed cost for heifer rearing of the same age group in the USA. Daily feed cost of heifer raising was about 2 times higher in Kuwait than that found in USA due to higher cost of imported feed in Kuwait.

Milk yield potential: In order to provide some indications of the likely impact, the "future" model has been presented (Table 6), which included improvements in breeding performance, nutrition, feeding practices and some cooling of the environment for the cows so that milk yields and breeding are not so adversely affected during the hot summer and humid periods in summer to autumn seasons. The impact on the operating surplus, even from a very conservative improvement in milk yields to 7,000 L per lactation/cow. It was observed that in rearing of dairy heifers for replacement purposes in the improved scenario without any changes in the milking herd structure would not result in producing sufficient numbers to completely replace the importation. The projected future (extended 10 years) will require additional capital costs, changes in herd structure, improved performance of milking herds. Thus an operating surplus was projected to be KD 136,322/(Table 6).

\section{CONCLUSION}

The results of the economic assessments showed that reducing calf mortality and raising heifers to enter the milking herd were both profitable activities, thus a small investment on facilities and additional inputs are worth undertaking. The benefits of similar improvements on a whole herd basis are expected to be 
much larger and further studies need to be undertaken to develop the technology and demonstrate the impact of intervention to the dairy industry in wider scale.

\section{ACKNOWLEDGEMENT}

Kuwait Foundation for the Advancement of Sciences (KFAS) provided partial financial grants. Authors thank dairy producers of Kuwait for providing farm facilities, dairy herds and partial financial assistance to the study. Specialized dairy economics help was provided by Mr. R.F. Woolcock of GRM International, Australia. Professional assistance of Ms. Mini Jacob, Ms. Sheeba Albert and Ms. Shalini Mathew in the laboratories and secretarial work of Ms. Shiji Thomas for the preparation of the paper are acknowledged.

\section{REFERENCES}

Bailey, T. and J. Currin, 1999. Heifer inventory and the economics of replacement rearing, Virginia cooperative extension. Virginia Tech and Virginia State University, USA, Virginia. Publication No. 404-287. http://pubs.ext.vt.edu/404/404-287/404-287.pdf

Bailey, T., 1999. Milk production evaluation in 1st lactation heifers. Virginia Regional College Veterinary Medicine.,Publication No. 404-285, Richmond, Virginia, USA. http://www.careerportals.com/cp/docs/pdf/first_lac tation_heifers.pdf

Baily, T.L., 1992. Economic considerations of dairy heifers. Proceeding of the Society for Theriogenology, San Antonio, Texas, pp: 56-59.

Gulliksen, S.M., K.I. Lie, T. Loken and O. Osteras, 2009. Calf mortality in Norwegian dairy herds. J. Dairy $\quad$ Sci., $\quad 92: \quad$ 2782-2795. http://jds.fass.org/cgi/content/abstract/92/6/2782

Harash, S., C. Wolf and E. Wittenberg, 1998. Dairy profitability and enterprise efficiency project report. Michigan State University Agricultural Economics, Staff Paper No. 2000.

Head, H.H., 1992. Heifer Performance Standards: Rearing Systems Growth Rates and Lactation. In: Large Herd Dairy Management, Van Horn, H.H. and C.I. Wilcox (Eds.). American Dairy Association II, Champaign, pp: 422-425.
Heersche, G., Nebel and R.L. Illinois, 1994. Measuring efficiency and accuracy of detecting of estrus. J. Dairy Sci., 77: 2754-2761. http://www.dairyscience.org/cgi/reprint/77/9/2754

Moore, R., J. Beiler and G. Schnitkey, 2009. The economics of heifer contracting. Ohio State University Factsheet, Animal Science, Publication No. AS-0060-00. http://ohioline.osu.edu/asfact/0006.html

Mourtis, M.C.M., A.A. Dijkhuizen, R.B.M. Huirne and D.T. Galligan, 1997. Technical and economic models to support heifer management decisions: Basic concepts. J. Dairy Sci., 80: 1406-1415. http://jds.fass.org/cgi/reprint/80/7/1406.pdf

Razzaque, M.A., S. Abbas and M. Bedair, 2009a. Mortality of pre-weaned calves in Kuwait's dairy herds, its causes and impact of interventions. Internet J. Vet. Med., 5: 1-12.

Razzaque, M.A., S. Abbas, T. Al-Mutawa and M. Bedair, 2009b. Performance of pre-weaned calves in confined housing and open environment hutches in Kuwait. Pak. Vet. J., 29: 1-4. http://pvj.com.pk/pdf-files/29_1/1-4.pdf

Razzaque, M.A., M. Bedair, S. Abbas and T. Al-Mutawa, 2009c. Economic impact of calf mortality on dairy farms in Kuwait. Pak. Vet. J., 29: 97-101. http://www.doaj.org/doaj?func=abstract\&id=429201

Razzaque, M.A., S.A. Mohammed, T. Al-Mutawa and M. Bedair, 2009d. Growth, reproduction and milk yield of Holstein Friesian heifers born and adapted in Kuwait. Pak. J. Nutr., 8: 1159-1163. http://www.pjbs.org/pjnonline/fin1312.pdf

Razzaque, M.A., S.A. Mohammed, T. Al-Mutawa and M. Bedair, 2009e. Improving performance of replacement heifers in hot arid environment under intensive management. Am. J. Anim. Vet. Sci., 4: 85-91. http://www.scipub.org/fulltext/AJAV/AJAV448591.pdf

Tenhagen, B.A., M. Drillich, R. Surholt and W. Heuwieser, 2004. Comparison of timed AI after synchronized ovulation to AI at Estrus: Reproductive and economic considerations. J. Dairy Sci., 87: 85-94. http://jds.fass.org/cgi/reprint/87/1/85 